\title{
Alluvial xenotime and heavy minerals assemblage from the northern edge of Nisa-Albuquerque Batholith, eastern Portugal: Provenance and geochemical implications
}

\author{
Rute Salgueiro $^{\mathrm{a}, *}$, Diogo Rosa ${ }^{\mathrm{b}}$, Carlos Inverno ${ }^{\mathrm{a}}$, Daniel de Oliveira ${ }^{\mathrm{a}}$, A. Rita Solá c ${ }^{\text {, Fernanda Guimarães }}{ }^{\mathrm{d}}$ \\ a LNEG, Unidade de Recursos Minerais e Geofisica, Ap. 7586 Alfragide, Portugal \\ b GEUS, Dept. of Petrology and Economic Geology, Geological Survey of Denmark and Greenland Oester Voldgade 10, DK-1350 Copenhagen K, Denmark \\ c LNEG, Unidade de Geologia, Hidrogeologia e Geologia Costeira, Ap. 7586 Alfragide, Portugal \\ ' LNEG, Unidade de Ciência e Tecnologia Mineral, Ap. 1089 S. Mamede de Infesta, Portugal
}

\section{A R T I C L E I N F O}

\section{Article history:}

Received 23 December 2013

Accepted 26 July 2014

Available online 3 August 2014

\section{Keywords:}

Xenotime chemistry

Alluvial heavy minerals

HREE enrichment

Eastern Portugal

\begin{abstract}
A B S T R A C T
The xenotime-bearing heavy mineral assemblages present in the alluvial samples from Vila Velha de Ródão, Nisa, Póvoa e Meadas and Sto. António das Areias, localized in the northern edge of Nisa-Albuquerque Batholith, Eastern Portugal, were studied in detail. The insights for mineral provenance came from the analysis of the drainage network and from the composition of the regional alluvial samples and outcropping lithologies. Since xenotime is a mineral with economic interest, the motivation of the current work is its contribution for exploration studies, considering the potential information contained in the alluvial samples. In the study region, the alluvial heavy minerals and their morphology reflect clearly the mineralogy and relative distance to their source, respectively. In alluvial samples with direct provenance from the Nisa granite (late Carboniferous), the increase in xenotime concentration and decrease in monazite, apatite, zircon, ilmenite and iron oxide concentration, from $\mathrm{W}$ (Nisa) to $\mathrm{E}$ (Sto. António das Areias), matches the increase in $\mathrm{P}_{2} \mathrm{O}_{5}$ and decrease in $\mathrm{REE}, \mathrm{CaO}, \mathrm{Zr}, \mathrm{TiO}_{2}$, and $\mathrm{Fe}_{2} \mathrm{O}_{3}$ contents in granite rocks. The geochemical signature of xenotime studied reveals an igneous source, characterized by the characteristic strong Eu negative anomaly in REE patterns. Their $\mathrm{YPO}_{4}$ values (72-78 mol\%) are similar to xenotime from Erzgebirge (Germany) granites. The high values of Y/Ho (50-71) and, in some cases, downward kinks at Ho in REE plots, suggest generation in late stages of crystallization and association with a siliceous evolved magmatic system. The slight decrease in HREE contents in xenotime, from W to E, and Ho anomalies in the normalized REE pattern are similar to those identified in the Nisa granite, which supports the sourcing of xenotime from these granitic rocks. The genetic development of the batholith chemical zonation (more evolved to E) seems to have favoured the generation of xenotime instead of apatite, monazite and zircon, in the eastern end area (Sto. António das Areias).

Supporting the geochemical signature, the alluvial zircons also display morphological typologies that are compatible with provenance from peraluminous granites formed at temperatures of $600-700{ }^{\circ} \mathrm{C}$, possibly from the Nisa granite. Since all xenotime grains show the same magmatic affinity, this leads to the hypothesis that the xenotime from the Vila Velha de Ródão sample, with provenance from Cenozoic sedimentary rocks, has been transported to this northern area, after been disaggregated from Nisa batholith granites, most probably by braided anastomosing and erratically sandy channels, that explains its actual position in the opposite bank of the Tagus river. This phosphate has been deposited with other sediments in tectonic depressions and subsequently included in the formation of sedimentary rocks. The greater development of $\mathrm{Ca}$, Th and $\mathrm{U}$ phosphate inclusions/substitutions in these xenotime grains can be explained by the chemical mobility provided during all the geological processes.
\end{abstract}

\section{Introduction}

Xenotime $\left(\mathrm{YPO}_{4}\right)$ is one of the few known yttrium minerals. This element is related to the Rare Earth Elements (REE), which are considered as critical raw materials for Europe, based on their economic

\footnotetext{
* Corresponding author.

E-mail address: rute.salgueiro@lneg.pt (R. Salgueiro).
}

importance and supply risks (European Commission, 2010). However, while mined together and having to undergo the same complex metallurgical recovery process, the elements of this group have differing demands and supplies. These elements are therefore not critical to the same extent, and it is to be expected that markets may be flooded by some elements while supply constraints remain for others. Among the latter, the United States Department of Energy (2011) has highlighted Y, together with Nd, Dy, Eu and Tb, as the most critical elements, both 